ПЕРИТ

Ірина Олегівна iperyt.mriya@i.ua

УдК 334.012;334.722; 330.341; 330.354 ДОХОДІВ ДОМОГОСПОДАРСТВ ВІД ПІДПРИЄМНИЦЬКОї ДІЯЛЬНОСТІ

\section{ANALYSIS OF THE STRUCTURE AND \\ DYNAMICS OF HOUSEHOLD INCOME FROM ENTREPRENEURIAL ACTIVITY}

DOI: https://doi.org/10.37634/efp.2020.9.3
БРИЧ

Василь Ярославович v.brych@tneu.edu.ua

\author{
магістр, м.н.с., \\ національний університет \\ (колишній Тернопільський \\ національний економічний \\ університет) \\ Західноукраӥнськии
}

\author{
о.е.н., професор, \\ Західноукрайнський начіональний \\ університет (колишній \\ Тернопільський національний \\ економічний університет), \\ Навчально-науковий інститут \\ інноваційних освітніх технологій
}

PERYT Iryna Olehivna - master, Junior Researcher, West Ukrainian National University (former Ternopil National Economic University)

BRYCH Vasyl Yaroslavovych - Doctor of Economics, Professor, West Ukrainian National University (former Ternopil National Economic University), Education and Research Institute of Innovative Educational Technologies

У статті досліджено склад та динаміку доходів домогосподарств від підприємницької діяльності у структурі громових доходів та сукупних ресурсів, у т.ч. за показниками величини населеного пункту, за регіонами та геолокацією. Інструментами корелячійно-регресійного аналізу визначено фактори впливу зовнішнього середовища на показники доходів домогосподарств від підприємницької діяльності, побудовано матрицю коефіцієнтів кореляційної моделі та отримано регресійні моделі. 3 а результатами проведеного дослідження визначено основні тенденції коливання доходів домогосподарств від підприємницькоі діяльності, сформовано та обтрунтовано авторське бачення сутності отриманих показників.

$* * *$

В статье исследовано состав и динамику доходов домохозяйств от предпринимательской деятельности в структуре денежных доходов и совокупных ресурсов, в т.ч. по показателям величины населенного пункта, по регионам и геолокации. Инструментами коррелячионно-регрессионного анализа определены факторы влияния внешней среды на показатели доходов домохозяйств от предпринимательской деятельности, построено матрииу коэффициентов корреляционной модели и получены регрессионные модели. По результатам проведенного исследования определены основные тенденции колебания доходов домохозяйств от предпринимательской деятельности, сформировано и обоснованно авторское видение сущьности полученных показателей.

Introduction. In conditions of modern economy, one of the indicators of economic development and the presence of positive environment for private business development is the household income level from entrepreneurship. But the instability of political and economic events in recent years has had a significant impact on private entrepreneurs activity. So the studying the structure and dynamics of household income from entrepreneurial activity today is an important area of research.

The purpose of the research is to analyze and establish the main trends in the development of household income from entrepreneurial activity in the structure of cash income and total resources.

Research methods. The methodological basis of the work is the conclusions and generalizations of economic science and scientific works on the subject of research the structure and dynamics of household income from entrepreneurial activity. The research uses logical, comparative and complex approaches, as well as methods of observation, comparison, graphical and complex analysis.

Results. The paper studies the composition and dynamics of household income from the sale of entrepreneurial skills implementation in the structure of cash income and total resources, which shows almost doubled household income from entrepreneurial activity in the sampling period, as well as a significant increase in household income from agricultural products sales and property income. Based on research of household income in the structure of cash income and total resources by geolocation, it was found that the highest level of household income from entrepreneurship activity is reached in large and small towns, and household income from agricultural products sales and household income from property - in villages. According to results of the analysis of household incomes from entrepreneurial skills implementation, depending on the region, it was found that the highest level was reached by the regions of western and central Ukraine, and Kyiv. Based on the tools of correlation and regression analysis, it was determined the main factors of environmental influences on household income from entrepreneurial activity, which are the fluctuations in the inflation index and gross domestic product (GDP).

Conclusion. Thus, the tendency to reduce of some income categories from entrepreneurial skills implementation, particularly in terms of income from agricultural products sales in rural households, which are the most sensitive to economic fluctuations, requires a comprehensive review and improvement of business conditions for small businesses at the national level.

The scientific value of study is to determine the main trends in household income from entrepreneurship activity, which will allow to get quality information on the private business development level, to use it to predict the future development of small business and in developing normative acts on state regulation of entrepreneurship.

Ключові слова: домогосподарство, підприємничька діяльність, підприємнииька діяльність домогосподарств, дохід, доходи від підприємницької діяльності, доходи від підприємницької діяльності домогосподарств, бізнес 
Ключевые слова: домохозяйство, предпринимательская деятельность, предпринимательская деятельность домохозяйств, доход, доходы от предпринимательской деятельности, доходы от предпринимательской деятельности домохозяйств, бизнес

Keywords: household, entrepreneurial activity, entrepreneurial activity of households, income, income from entrepreneurial activity, income from entrepreneurial activity of households, business

\section{ВСТУП}

Доходи домогосподарств від підприємницької діяльності є одним із основних індикаторів показників прибутковості та успішності власної справи приватних підприємців. 3 іншого боку, дана категорія доходу напряму впливає на рівень розвитку вітчизняної економіки та суспільства загалом. Однак політичні та суспільні тренди останніх років характеризувалися нестабільністю та спричинили значний вплив на діяльність суб'єктів господарювання і на розвиток економіки загалом. Зокрема, варто згадати укладання угоди про зону вільної торгівлі з СС, податкові зміни, початок бойових дій у східних регіонах України, обмеження співпраці із Росією тощо. Саме тому дослідження структури та динаміки доходів домогосподарств від підприємницької діяльності сьогодні $€$ актуальним напрямком дослідження.

\section{Аналіз досліджень та публікацій}

В умовах сучасної економіки проведено безліч наукових досліджень стосовно вивчення структури та динаміки показників доходів домогосподарств від підприємницької діяльності. Зокрема, на нашу думку, найбільш вагомими напрацюваннями цього напрямку дослідження є праці таких сучасних науковців як I. Дворник, А. Заїка, Т. Кізима, І. Козлова, Л. Лілич, С. Мостенець, С. Потьомкін, А. Семенченко тощо [1-6]. Проте тематика цього дослідження є динамічною, що зумовлює необхідність актуалізації інформації у періодах вибірки.

\section{МЕТА РОБОТИ}

Оскільки рівень розвитку приватного бізнесу домогосподарств $є$ як показником наявності сприятливого економічного середовища для ведення власної справи, так і впливає на рівень вітчизняного економічного розвитку, то у нашому дослідженні поставлено за мету проведення горизонтального, вертикального, кореляційно-регресійного аналізу та встановлення основних трендів структури і величини доходів домогосподарств від підприємницької діяльності у структурі грошових доходів та сукупних ресурсів, у т.ч. за величиною населеного пункту, регіонами та геолокацією.

\section{МЕТОДИ ДОСЛІДЖЕННЯ}

Методологічну основу роботи становлять висновки й узагальнення економічної науки та наукові праці з дослідження структури та динаміки доходів домогосподарств від підприємницької діяльності. У роботі застосовано логічний, порівняльний та комплексний підходи, а також методи спостереження, порівняння, графічного та комплексного аналізу.

\section{РЕЗУЛЬТАТИ}

Особливості сучасної економіки показують, що рівень розвитку підприємницької діяльності домогосподарств є одним із основних індикаторів економіч- ної стабільності держави, адже великі підприємства не в змозі задовольнити потреби усіх без винятку груп споживачів. Великий бізнес в основному працює на уніфікованого покупця, а приватні підприємці малого та мікробізнесу продають продукцію та послуги, виробництво яких $є$ невигідним для великих гравців ринку. До того ж підприємницька діяльність «...визначає рушійні сили і характер розвитку системи, що складає структурно-змістовне наповнення категорії «рівень життя населення»... Саме необхідність реалізації тієї або іншої потреби спонукає індивіда до активних дій, спілкування, виробничої, творчої або підприємницької діяльності [7, с. 349]. Тобто рівень розвитку підприємницької діяльності домогосподарств, незалежно від напрямку діяльності чи форми власності, напряму показує рівень добробуту громадян.

Також варто зауважити, що більшість досліджень підприємницької діяльності домогосподарств аналізують їх виключно як фізичних осіб підприємців, самозайнятих осіб чи власників надомного незареєстрованого бізнесу. Однак за результатами раніше проведених нами наукових пошуків, ми дійшли висновку та акцентуємо увагу на тому, що підприємницька діяльність домогосподарств включає також трактування домогосподарства як власника бізнесу макромасштабу, як власника середнього бізнесу, як власника мікробізнесу [8, с. 70] Тобто домогосподарства здійснюють пряму або опосередковану участь в управлінні юридичними організаціями, які є їх власністю та отримують доходи від діяльності.

Однак дані Державного комітету статистики з досліджень підприємницьких доходів домогосподарств містять виключно інформацію про діяльність приватних підприємців, самозайнятих осіб, доходи від продажу сільськогосподарської продукції та доходи від власності, а динаміка дохідності юридичних осіб аналізується окремо, до того ж аналітичне наповнення цих показників суттєво різниться.

Тому, якщо говорити про домогосподарства як про індивіда чи угрупування індивідів, які здійснюють незареєстровану або зареєстровану як ФОП діяльність, то варто детальніше проаналізувати структуру i динаміку таких категорій доходів домогосподарств як: доходи домогосподарств від підприємницької діяльності, доходи від продажу сільськогосподарської продукції та доходи від власності (дивіденди від акцій, здачі активів у найм тощо). Для аналізу обрано період 2014-2018 рр., адже на момент проведення дослідження на офіційному ресурсі Державної служби статистики були відсутніми окремі дані за 2019 р.

Так, для цілісної та чіткої картини проведемо горизонтальний та вертикальний аналіз даних Державної служби статистики щодо динаміки доходів домогосподарств від підприємницької діяльності [9-11].

Дослідивши сукупні ресурси домогосподарств у 2014-2018 pр., бачимо, що левову частку у їх струк- 
турі займають доходи від оплати праці, які характеризуються зростаючою тенденцією, а їх найвищий показник зафіксовано у 2018 р. на рівні 54,5 \%, у т.ч. у міських домогосподарств - 60,2 \%, у сільських 41,6 \%. Значну частку у структурі сукупних ресурсів домогосподарств займають доходи від пенсій, стипендій, допомоги та субсидії, надані готівкою. Їх найвищий зафіксовано у 2014 р. у міських домогосподарств на рівні 26,1 \%, у сільських - 28,5 \%. Проте у наступних роках бачимо спадну тенденцію цього показника: у 2018 р. - зниження до 19,9 \% у міських домогосподарств та до 20,8 \% у сільських домогосподарств.

Досить чітко можна прослідкувати динаміку зростання доходів домогосподарств від підприємницької діяльності та самозайнятості у структурі сукупних ресурсів: у міських домогосподарств - показник зріс із $5,3 \%$ у 2014 р. до 6,4\% у 2018 р., у сільських - у 2014-2017 рр. бачимо спадну тенденцію із 5,1 \% до $3,5 \%$, проте у 2018 р. показник зріс до позначки 5,1\%.

Серед сільських домогосподарств значну вагу мають також доходи від продажу с/г продукції та грошова допомога від родичів і інші грошові доходи. Так, доходи від продажу с/г продукції сільських домогосподарств у структурі сукупних ресурсів становили 9,5 \% у 2015 р., а у 2018 р. знизилися до 7,2 \%. Вартість спожитої продукції, отриманої з особистого підсобного господарства та від самозаготівель знизи- лася 3 11,1 \% у 2014 р. до 9,6 \% у 2018 р. Натомість розмір грошової допомоги від родичів та інших грошових доходів у структурі сукупних ресурсів сільських домогосподарств характеризувався позитивним трендом - показник зріс із 7,8 \% у 2014 р. до 9,6 \% у 2018 р. 3 іншого боку, у міських домогосподарств доходи від продажу с/г продукції у структурі сукупних ресурсів у 2014-2018 рр. коливалися на рівні 0,4\%, грошова допомога від родичів та інших грошових надходжень - 7,6-6\%, а вартість спожитої продукції, отриманої із особистого підсобного господарства та від самозаготівель - $1,5 \%$.

Розглянемо детальніше структуру і динаміку доходів домогосподарств від підприємницької діяльності: доходи домогосподарств від підприємницької діяльності, доходи від продажу сільськогосподарської продукції та доходи від власності (рис. 1-4). Так, ланцюговий темп приросту доходів домогосподарств від підприємницької діяльності у структурі сукупних ресурсів у 2014-2018 рр. в середньому становив 5,32\% та вдвічі перевищував показник ланцюгового приросту доходів від оплати праці. Базисний темп приросту доходів домогосподарств від підприємницької діяльності у структурі сукупних ресурсів у 2014-2018 рр. в середньому становив 1,44 \%, що менше показника приросту доходів від оплати праці.

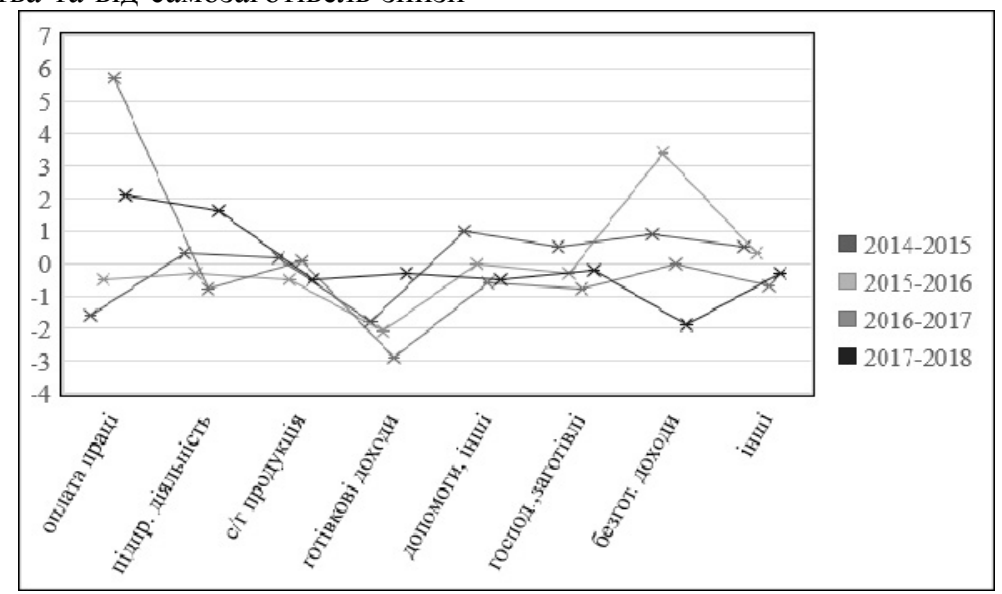

Рис. 1. Ланцюгговий абсолютний приріст сукупних ресурсів домогосподарств, \% [розроблено автором]

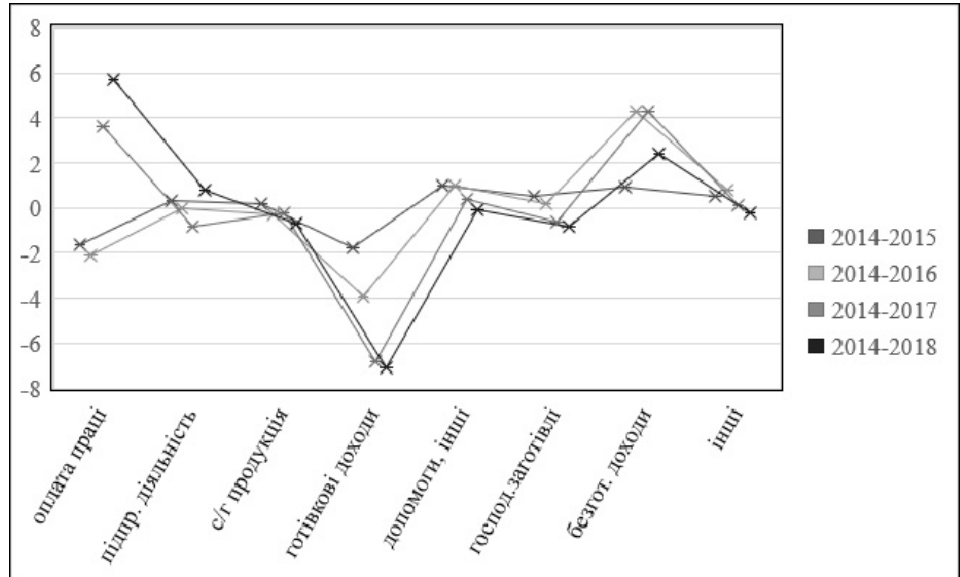

Рис. 2. Базисний абсолютний приріст сукупних ресурсів домогосподарств, \% [розроблено автором] 


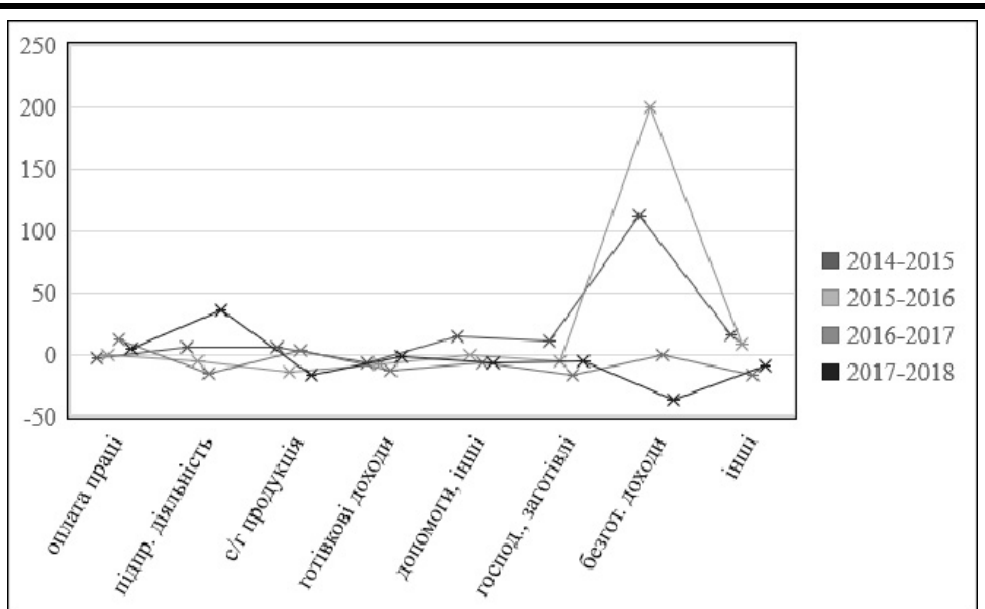

Рис. 3. Ланцююговий темп приросту сукупних ресурсів домогосподарств, \% [розроблено автором]

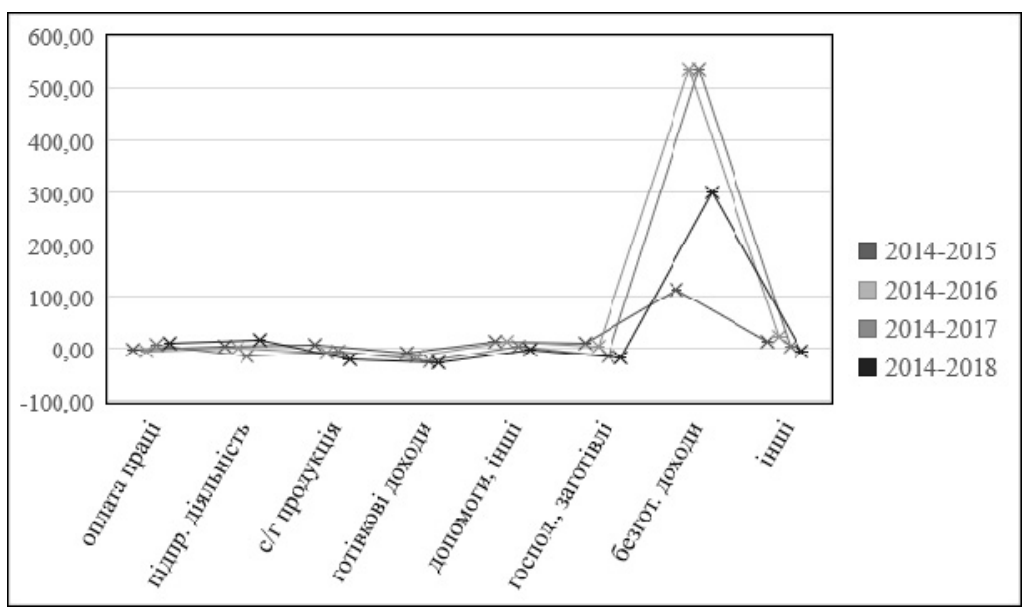

Рис. 4. Базисний темп приросту сукупних ресурсів домогосподарств, \% [розроблено автором]

Доходи домогосподарств від підприємницької діяльності у структурі грошових доходів і сукупних ресурсів в середньому на одне домогосподарство у 2018 р. становили 592,77 грн., що майже вдвічі більше ніж у 2014 р. (238,5 грн). У 2018 р. ланцюговий та базисний абсолютний приріст становили 227,5 \% та 354,27\% відповідно, абсолютний темп приросту ланцюговий та базисний - 62,26 \% та 148,54 \% відповідно (рис. 5), що свідчить про покращення економічних умов для розвитку бізнесу.

Доходи домогосподарств від продажу с/г продукції у структурі грошових доходів і сукупних ресурсів в середньому на одне домогосподарство найвищого рівня досягли у 2018 р. - 248,4 грн., що на 100 грн. більше, ніж у 2014 р. Найвищий показник ланцюго- вого та базисного абсолютного приросту становив 29,34 \% у 2015 р. та 99,56 \% у 2018 р. відповідно, а найбільший ланцюговий і базисний темп приросту $19,71 \%$ у 2015 р. та $66,89 \%$ у 2018 р. (рис. 6).

Доходи домогосподарств від власності (дивіденди від акцій, здачі активів у найм тощо) у структурі грошових доходів і сукупних ресурсів в середньому на одне домогосподарство найвищого рівня досягли у 2018 р. - 130,3 грн., що на 85,89 грн. більше, ніж у 2014 р. Найвищий показник ланцюгового та базисного абсолютного приросту становив 31,03\% у 2016 р. та 85,89 \% у 2018 р., а найбільший ланцюговий і базисний темпи приросту бачимо на рівні 52,69 \% у 2016 р. та 193,4 \% у 2018 р. відповідно (рис. 7).

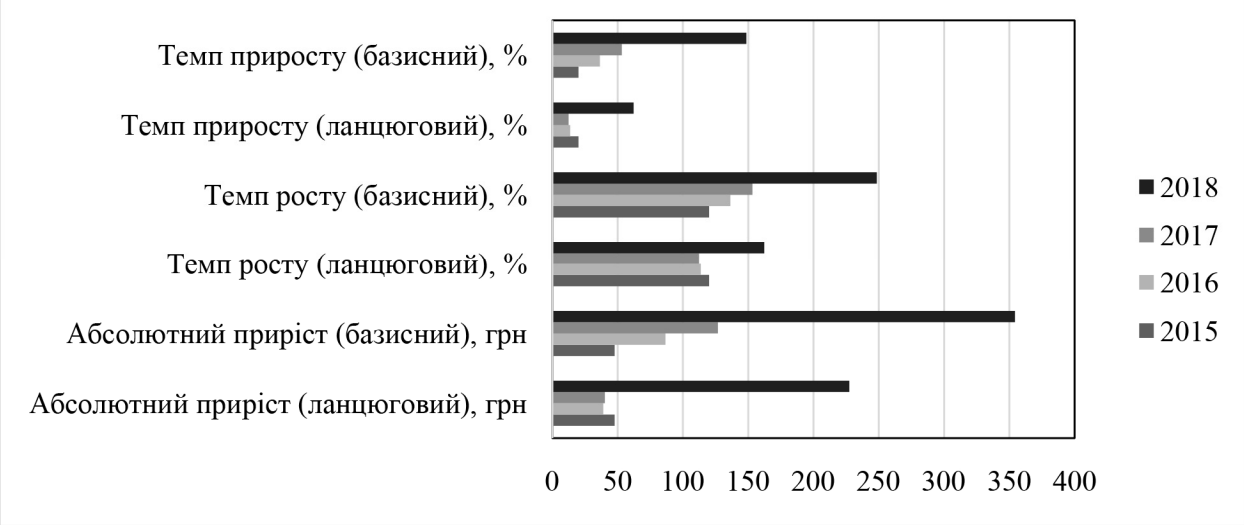

Рис. 5. Показники доходів домогосподарств від підприємнищької діяльності та самозайнятості у структурі громових доходів і сукупних ресурсів у середньому на одне домогосподарство (грн.) [розроблено автором] 


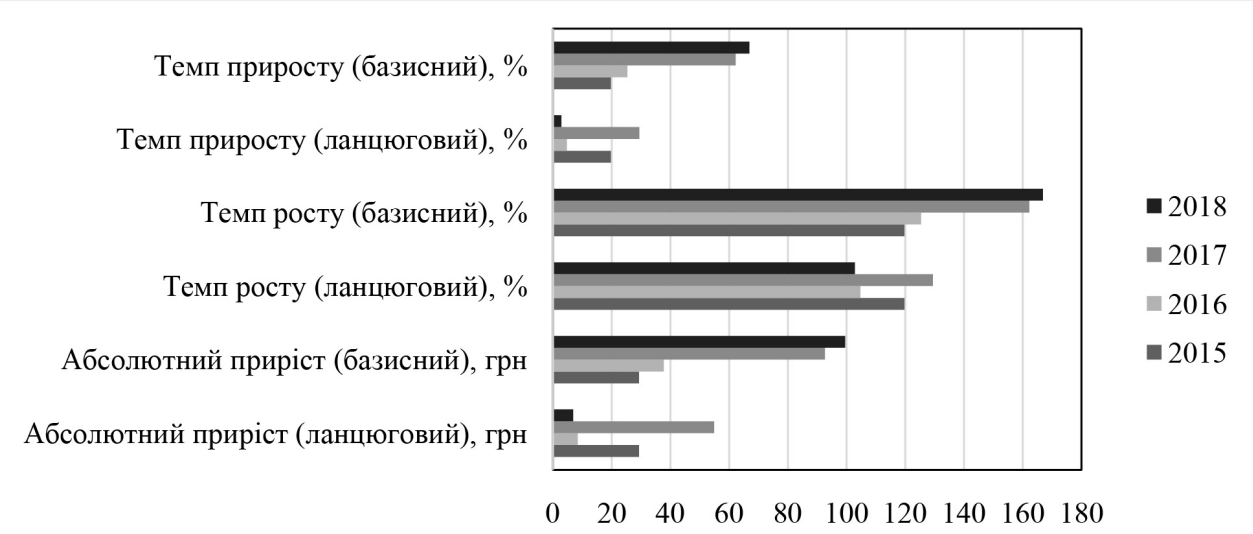

Рис. 6. Показники доходів домогосподарств від продажу сільськогосподарської продукиії у структурі грошових доходів і сукупних ресурсів, в середньому на домогосподарство (грн.) [розроблено автором]

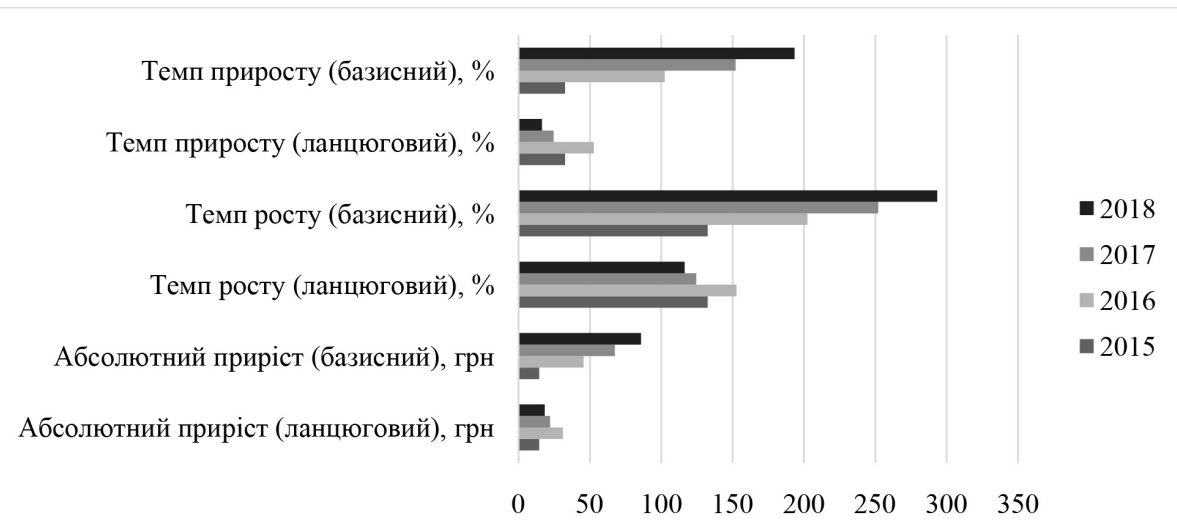

Рис. 7. Показники доходів домогосподарств від власності (дивіденди від акцій, здачі активів у найм тощзо) в структурі грошових доходів і сукупних ресурсів, в середньому на домогосподарство (грн.) [розроблено автором]

Аналізуючи місце доходів домогосподарств від підприємницької діяльності, доходів від продажу с/г продукції та від власності (дивіденди від акцій, здачі активів у найм тощо) окремо у структурі сукупних ресурсів та в структурі грошових доходів, можемо сказати, що:

1. У структурі сукупних ресурсів: доходи домогосподарств від підприємницької діяльності на одне домогосподарство за місяць займають основну частину доходів домогосподарств від реалізації підприємницького хисту, зокрема у великих містах найвищі показники зафіксовано у 2015 р. на рівні 6,2 \% та у 2018 р. - на рівні 5,9 \%, у малих містах: у 2018 р. - 7,3\%, у селах: у 2018 р. - 5,1 \%; доходи від продажу с/г продукції у структурі сукупних ресурсів у великих та малих містах коливалися на рівні 0,1 \% та 0,9-1,3 \% відповідно, а у селах показник знизився із 9,2 \% до 7,2 \%; дивіденди від акцій, від здачі у найм та інші доходи від власності в структурі грошових доходів у великих та малих містах перебували на позначці 0,2 \% та 0,5 \% відповідно, а у селах $-2,3-3,7 \%$.

2. У структурі грошових доходів: доходи домогосподарств від підприємницької діяльності на одне домогосподарство за місяць також становлять левову частку доходів домогосподарств від реалізації підприємницького хисту, зокрема у великих містах найвищі показники зафіксовано у 2015 р. на рівні 6,6 \%, у малих містах: у 2018 р. - 8,1\%, у селах: у 2018 р. 6,0 \%; доходи від продажу с/г продукції у структурі грошових доходів у великих та малих містах перебували на рівні $0,1 \%$ та $1-1,5 \%$ відповідно, а у селах показник знизився із 10,8 \% до $8,6 \%$; дивіденди від акцій, від здачі у найм та інші доходи від власності У структурі грошових доходів у великих та малих містах перебували на позначці 0,1 \% та 0,6 \% відповідно, а у селах показник збільшився з 2,7 \% до 4,4 \%.

Проаналізуємо динаміку доходів домогосподарств від підприємницької діяльності за геолокацією бізнесу:

1. Найвищі доходи домогосподарств від підприємницької діяльності у структурі грошових доходів і сукупних ресурсів в середньому на одне домогосподарство за геолокацією бачимо у 2018 р.: у великих містах - 625,48 грн., у малих містах - 674,92 грн., у селах - 482,81 грн.; ланцюговий абсолютний приріст: у великих містах - 249,08 грн., у малих містах - 227,35 грн., у селах - 221,23 грн.; базисний абсолютний приріст: у великих містах - 356,93 грн., у малих містах - 465,75 грн., у селах - 256,87 грн.; ланцюговий темп росту: у великих містах $-166,17 \%$, у малих містах - 157,75 \% (2017 р.), у селах - 171,46 \%; базисний темп росту: у великих містах - 232,91 \%, у малих містах - 322,67\%, у селах - 213,69\%; ланцюговий темп приросту: у великих містах - 66,17\%, у малих містах - 57,75\% (2017 р.), у селах - 71,46 \%; базисний темп приросту: у великих містах $-132,91 \%$, у малих містах $-222,67 \%$, у селах $-113,69 \%$.

2. Найвищі показники доходів домогосподарств від продажу с/г продукції у структурі грошових доходів і 
сукупних ресурсів у середньому на одне домогосподарство у розрізі геолокації зафіксовано: у великих містах: у 2015 р. - 4,56 грн, у малих містах: у 2018 р. - 88,13 грн, у селах: у 2018 р. - 684,22 грн.; ланцюговий абсолютний приріст: у великих містах: у 2015 р. 1,7 грн, у малих містах: у 2016 р. - 23,73 грн, у селах: у 2017 р. - 156,05 грн.; базисний абсолютний приріст: у великих містах: у 2015 р. - 1,7 грн., у малих містах: у 2018 р. - 45,52 грн, у селах: у 2018 р. - 273,71 грн.; ланцюговий темп росту: у великих містах: у 2015 р. 159,44 \%, у малих містах: у 2016 р. - 149,12 \%, у селах: у 2017 р. - 130,8 \%; базисний темп росту: у великих містах: у 2015 р. - 159,44 \%, у малих містах: у 2018 р. - 206,83 \%, у селах: у 2018 р. - 166,68 \%; ланцюговий темп приросту: у великих містах: у 2015 р. - 59,44\%, у малих містах: у 2016 р. - 49,12\%, у селах: у 2017 р. - 30,8 \%; базисний темп приросту: у великих містах у 2015 р. - 59,44 \%, у малих містах: у 2018 р. 106,83 \%, у селах: у 2018 р. $-66,68 \%$.

3. Найвищі показники доходів домогосподарств від власності (дивіденди від акцій, здачі активів у найм тощо) у структурі грошових доходів і сукупних ресурсів в середньому на одне домогосподарство у розрізі геолокації зафіксовано: у великих містах: у 2014 р. 13,77 грн., в малих містах: у 2018 р. - 47,74 грн, у селах: у 2018 р. - 352,55 грн.; ланцюговий абсолютний приріст: у великих містах: у 2014-2018 рр. від'ємний, у малих містах: у 2017 р. - 9,76 грн, у селах: у 2016 р. - 94,13 грн.; базисний абсолютний приріст: у великих містах у 2014-2018 рр. від'ємний, у малих містах: у 2018 р. - 27,63 грн, у селах: у 2018 р. - 251,6 грн.; ланцюговий темп росту: у великих містах: у 2015 р. 77,63 \%, у малих містах: у 2017 р. - 131,15 \%, у селах у 2016 р. - 164,73 \%; базисний темп росту: у великих містах: у 2015 р. - 77,63 \%, у малих містах: у 2018 р. 237,39 \%, у селах: у 2018 р. - 349,23\%; ланцюговий темп приросту: у великих містах: у 2014-2018 рр. від'ємний, у малих містах: у 2016 р. - 49,12\%, у селах: у 2016 р. - 64,73\%; базисний темп приросту: у великих містах у 2014-2018 рр. від'ємний, у малих містах: у 2018 р. $-137,39 \%$, у селах у 2018 р. $-249,23 \%$.

Якщо ж порівняти досліджену нами динаміку доходів домогосподарств за геолокацією у 2014-2018 pp. із попередніми періодами, бачимо, що кілька років поспіль до 2014 р. спостерігалася чітко виражена спадна тенденція [12, с. 217], проте з 2014 р. динаміка показує суттєвий позитивний приріст.

Проведемо аналіз динаміки доходів домогосподарств від підприємницької діяльності за регіонами:

1. Найвищий показник доходів домогосподарств від підприємницької діяльності та самозайнятості у структурі грошових доходів та сукупних ресурсів зафіксовано у Закарпатській області - 1466,57 грн. у 2014 р. iз зростаючою динамікою до 3577,14 грн. у 2018 р. (абсолютний базисний приріст 2110,57 грн, базисний темп приросту - 143,91\%), а найнижчий у Житомирській області - показник зменшився 3 138,8 грн у 2014 р. до 11,93 грн. у 2018 р. (абсолютний базисний приріст - -126,87 грн., базисний темп приросту -91,40 \%). Найбільший базисний абсолютний приріст доходів домогосподарств від підприємницької діяльності у структурі грошових доходів та сукупних ресурсів у середньому на місяць на одне домогоспо- дарство бачимо у Тернопільській, Чернігівській, Вінницькій, Донецькій, Запорізькій областях та м. Києві (від 771 грн. до 530 грн.), а найнижчий - у Житомирській і Харківській областях (-126,87 грн., та -47,3 грн. відповідно). Найвищий базисний темп приросту зафіксовано у Луганській і Рівненській областях (547,9 \% та 544,2 \% відповідно), найнижчий - у Житомирській і Харківській областях (-91,4 \% та -23,0 \% відповідно).

2. Найбільший показник доходів домогосподарств від підприємницької діяльності та самозайнятості у структурі грошових доходів бачимо у Закарпатській області - 28,5 \% у 2014 р. та 38,2 \% у 2018 р. (абсолютний базисний приріст - 2,7 \%, базисний темп приросту - 9,47\%), а найнижчий у Житомирській області - показник знизився з 3,7\% у 2014 р. до 0,1\% у 2018 р. (абсолютний базисний приріст становив - $-3,6 \%$, базисний темп приросту - -97,3\%). Найвищий базисний абсолютний приріст доходів домогосподарств від підприємницької діяльності у структурі грошових доходів у середньому на місяць на одне домогосподарство зафіксовано у Тернопільській, Чернігівській, Донецькій, Запорізькій областях (у діапазоні 5,0 \% - 5,9\%), а найнижчий - у Житомирській, Чернівецькій та Херсонській областях (від $-4,4$ \% до -3,2 \%). Найбільший базисний темп приросту зафіксовано у Донецькій, Запорізькій та Чернігівській областях (від 155,3\% до 164,5 \%), найнижчий - у Житомирській і Харківській областях (-97,3 \% та -60,4 \% відповідно).

3. Найвищий показник доходів домогосподарств від підприємницької діяльності та самозайнятості у структурі сукупних ресурсів зафіксовано у Закарпатській області - показник зріс з 25,1 \% у 2014 р. до 27,9 \% у 2018 р. (абсолютний базисний приріст - 2,8 \%, базисний темп приросту - 11,16\%), а найнижчий у Житомирській області - показник зменшився з 3,4 \% у 2014 р. до $0,1 \%$ у 2018 р. (абсолютний базисний приріст становив - $-3,3 \%$, базисний темп приросту -97,06 \%). Найбільший базисний абсолютний приріст доходів домогосподарств від підприємницької діяльності у структурі сукупних ресурсів в середньому на місяць на одне домогосподарство бачимо у Чернігівській, Тернопільській та Запорізькій областях(5,0 \% 4,7 \% відповідно), а найнижчий - у Житомирській і Чернівецькій областях (-4,3\% та $-3,9 \%$ відповідно). Найвищий базисний темп приросту зафіксовано у Луганській та Рівненській областях (200,0 \%), найнижчий - у Житомирській області (-97,06 \%).

Проведемо аналіз динаміки доходів домогосподарств від продажу сільськогосподарської продукції за регіонами:

1. Найбільший показник доходів домогосподарств від продажу с/г продукції у структурі грошових доходів та сукупних ресурсів бачимо у Волинській області - 178,8 грн. у 2014 р. із зростаючою динамікою до 531,88 грн. у 2018 р. (абсолютний базисний приріст - 353,08 грн, базисний темп приросту - 197,47 \%), а найнижчий - у Дніпропетровській області - показник зменшився з 84,7 грн. у 2014 р. до 80,98 грн. у 2018 р. (абсолютний базисний приріст становив -3,72 грн, базисний темп приросту - -4,39\%). Найвищий базисний абсолютний приріст доходів домогосподарств від продажу с/г продукції у структурі грошових доходів та 
сукупних ресурсів в середньому на місяць на одне домогосподарство спостерігаємо у Тернопільській області (404,48 грн.), а найнижчий - у Черкаській області (-5,64 грн.), а також у Дніпропетровській і Запорізькій областях (-3,72 грн. та $-1,96$ грн. відповідно). Найвищий базисний темп приросту зафіксовано у Тернопільській області (435,25\%), найнижчий - у Дніпропетровській і Черкаській областях (-4,39\% та -2,46 \% відповідно).

2. Найвищий показник доходів домогосподарств від продажу с/г продукції у структурі грошових доходів спостерігаємо у Волинській області - 4,7 \% у 2014 р., та 6,2 \% у 2018 р. (абсолютний базисний приріст - 1,5 \%, базисний темп приросту - 31,91\%), а найнижчий у Дніпропетровській області - показник знизився з 2,1\% у 2014 р. до 0,9 \% у 2018 р. (абсолютний базисний приріст - -1,2\%, базисний темп приросту - -57,14\%). Найбільший базисний абсолютний приріст доходів домогосподарств від продажу с/г продукції у структурі грошових доходів у середньому на місяць на одне домогосподарство бачимо у Тернопільській області $(3,1 \%)$, а найнижчий - у Черкаській, Вінницькій та Запорізькій областях (від $-3,3 \%$ до $-3,0 \%$ ). Найбільший базисний темп приросту бачимо у Тернопільській області (124,0 \%), найнижчий - у Дніпропетровській, Запорізькій і Черкаській областях (понад $--50 \%)$.

3. Найбільший показник доходів домогосподарств від продажу с/г продукції у структурі сукупних ресурсів зафіксовано у Луганській області - показник знизився з 6,3\% у 2014 р. до 5,7 \%. у 2018 р. проте залишився найвищим на території України (абсолютний базисний приріст становив $-0,6 \%$, базисний темп приросту - -9,52 \%), а найнижчий у Дніпропетровській області - показник зменшився з 2,0 \% у 2014 р. до $0,8 \%$ у 2018 р. (абсолютний базисний приріст становив -1,2\%, базисний темп приросту - -60,0%). Найбільший базисний абсолютний приріст доходів домогосподарств від продажу с/г продукції у структурі сукупних ресурсів у середньому на місяць на одне домогосподарство бачимо у Тернопільській області (2,5\%), а найнижчий - у Черкаській області $(-3,0 \%)$. Найвищий базисний темп приросту зафіксовано у Тернопільській області $(113,64 \%)$, найнижчий - у Дніпропетровській, Черкаській та Запорізькій областях (-60,0 \% $--50,0 \%)$.

Проаналізуємо доходи домогосподарств від власності за регіонами:

1. Найвищий показник доходів домогосподарств від власності (дивіденди від акцій, здача активів у найм тощо) у структурі грошових доходів та сукупних ресурсів зафіксовано у Кіровоградській області - 113,82 грн. у 2014 р. із зростаючою динамікою до 347,33 грн. у 2018 р. (абсолютний базисний приріст - 233,51 грн, базисний темп приросту - 205,16\%), а найнижчий - у Рівненській області - 3,12 грн. у 2014 р. зі зниженням до нуля у 2018 р.(абсолютний базисний приріст в $-3,12$ грн., базисний темп приросту - -100,0\%). Найбільший базисний абсолютний приріст доходів домогосподарств від власності (дивіденди від акцій, здача активів у найм тощо) у структурі грошових доходів та сукупних ресурсів у середньому на місяць на одне домогосподарство зафіксовано у Тернопільській об- ласті (257,13 грн.), а найнижчий - у Рівненській області (-3,12 грн.), а також у Закарпатській області та м. Київ (7,32 грн. та 7,03 грн. відповідно). Найвищий базисний темп приросту зафіксовано у Донецькій області (697,6\%), найнижчий - у Рівненській області $(-100,0 \%)$.

2. Найбільший показник доходів домогосподарств від власності (дивіденди від акцій, здача активів у найм тощо) у структурі грошових доходів бачимо у Хмельницькій області - 2,0\% у 2014 р., а у 2018 р. показник зріс до 3,5\% у 2018 р. (абсолютний базисний приріст $-1,5 \%$, базисний темп приросту $-75,0 \%$ ), а найнижчий у Рівненській області - показник знизився з $0,1 \%$ у 2014 р. до нуля у 2018 р. (абсолютний базисний приріст становив - $-0,1 \%$, базисний темп приросту $--100,0 \%)$. Найбільший базисний абсолютний приріст доходів домогосподарств від власності (дивіденди від акцій, здача активів у найм тощо) у структурі грошових доходів у середньому на місяць на одне домогосподарство спостерігаємо у Тернопільській області - 2,2 \%, а найнижчий - у Запорізькій області (-1,3\%). Найвищий базисний темп приросту зафіксовано у Донецькій області (250,0 \%), найнижчий - у Запорізькій області (-39,39\%).

3. Найвищий показник доходів домогосподарств від власності (дивіденди від акцій, здача активів у найм тощо) у структурі сукупних ресурсів бачимо у Кіровоградській області - показник зріс з 3,0 \% у 2014 р. до $3,9 \%$. у 2018 р. (абсолютний базисний приріст $0,9 \%$, базисний темп приросту - 30,0\%), а найнижчий у Рівненській області - показник знизився з $0,1 \%$ у 2014 р. до нуля у 2018 р. (абсолютний базисний приріст становив - $-0,1 \%$, базисний темп приросту - $-100,0 \%)$. Найбільший базисний абсолютний приріст доходів домогосподарств від власності у сукупних ресурсів у середньому на місяць на одне домогосподарство зафіксовано у Тернопільській області (1,9\%), а найнижчий - у Запорізькій області (-1,2 \%). Найвищий базисний темп приросту спостерігаємо у Донецькій області $(200,0 \%)$, найнижчий - у Рівненській області (-100,0 \%).

Для того щоб об'єктивно проаналізувати динаміку зміни доходів домогосподарств від підприємницької діяльності оцінимо ступінь впливу індексу інфляції, ВВП та індексу девальвації гривні (рис. 8) на величину доходів домогосподарств від підприємницької діяльності у 2014-2018 рр. У табл. 1 побудуємо матрицю кореляційних коефіцієнтів.

Провівши аналіз отриманих коефіцієнтів кореляції, бачимо, що на динаміку доходів домогосподарств від підприємницької діяльності найбільший ступінь впливу мав рівень ВВП, значення якого дорівнює 0,9309193 та значно перевищує за модулем 0,85 . Також варто звернути увагу на високий мультиколініарний зв'язок між такими факторами, як індекс девальвації гривні та ВВП. Тому для подальшого регресійного аналізу обрано фактори індексу інфляції та ВВП. Отже, величина коефіцієнта множинної кореляції $\mathrm{R}=0,9326941$ показує якість отриманої моделі. Значення R-квадрату показує, що на 87 \% на динаміку доходів домогосподарств від підприємницької діяльності вплинули обрані нами фактори, а $13 \%$ становлять фактори, які залишилися поза аналізом. 
Значення показника значущості $F$ свідчить про достовірність оцінювання. Отримано модель:

$$
Y=-163,08518+0,7759864 * I I+0,172363 * B B \Pi \text {. }
$$

Результат регресійного аналізу показує, що за збільшення індексу інфляції на 100 од. доходи домогосподарств від підприємницької діяльності знизяться на 77,6 од., а за збільшення ВВП на 100 од. - зростуть на

\section{7,2 од.}

Оцінимо ступінь впливу індексу інфляції, ВВП і індексу девальвації гривні (рис. 8) на величину доходів домогосподарств від продажу с/г продукції у 2014-2018 pр. У табл. 2 побудуємо матрицю кореляційних коефіцієнтів.

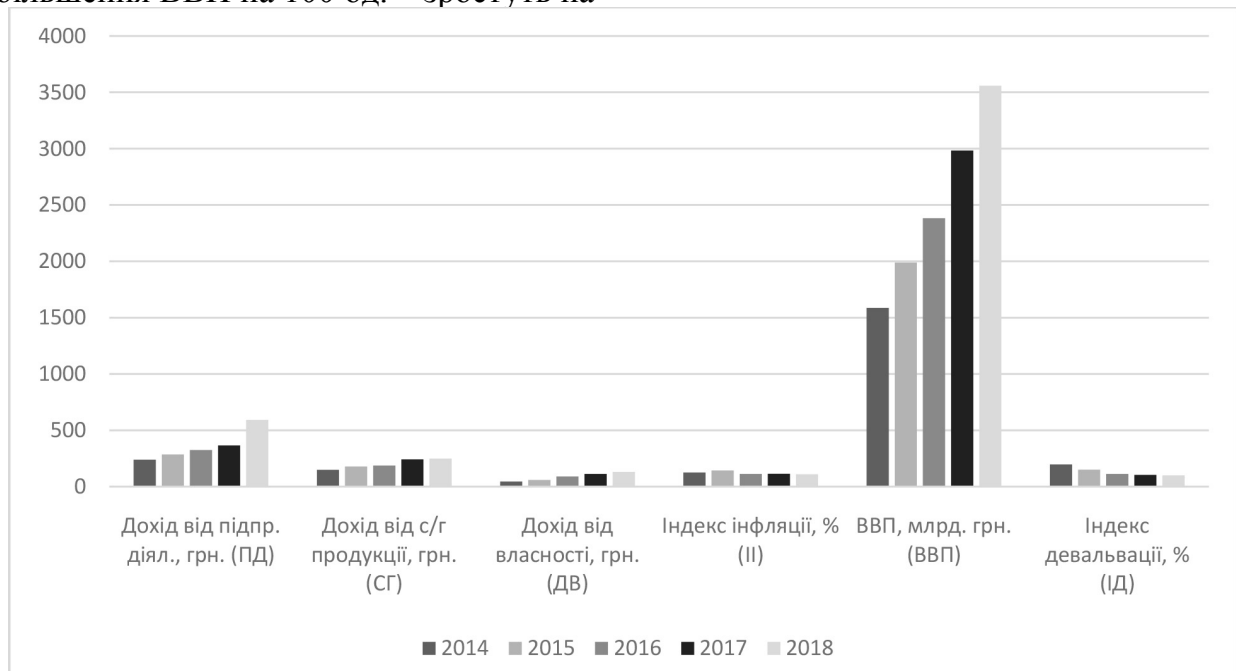

Рис. 8. Порівняння динаміки вихідних даних для кореляційно-регресійного аналізу впливу зовнішніх факторів на доходи домогосподарств від підприємницької діяльності, від продажу с/г продукиії, від власності [розроблено автором]

Таблиця 1

Матриця коефіцієнтів кореляційної моделі впливу зовнішніх факторів на доходи домогосподарств від підприсмницької діяльності у 2014-2018 рр. [розроблено автором]

\begin{tabular}{|c|c|c|c|c|}
\hline & ПД & II & ВВП & ІД \\
\hline ПД & 1 & & & \\
\hline II & $-0,586952$ & 1 & & \\
\hline ВВП & 0,9309193 & $-0,67603$ & 1 & 1 \\
\hline ІД & $-0,721336$ & 0,617597 & $-0,88521$ & \\
\hline
\end{tabular}

Таблиця 2

Матриця коефіціснтів кореляційної моделі впливу зовнішніх факторів на доходи домогосподарств від продажу сільськогосподарської продукції у 2014-2018 рр. [розроблено автором]

\begin{tabular}{|c|c|c|c|c|}
\hline & СГ & ІІ & ВВП & ІД \\
\hline СГ & 1 & & & \\
\hline IІ & $-0,59739$ & 1 & & \\
\hline ВВП & 0,972511 & $-0,67603$ & 1 & 1 \\
\hline ІД & $-0,87754$ & 0,617597 & $-0,88521$ & \\
\hline
\end{tabular}

Аналізуючи отримані коефіцієнти кореляції, бачимо, що на динаміку доходів домогосподарств від продажу с/Г продукції найвищий вплив мав рівень ВВП, що дорівнює 0,972511 та значно перевищує модульне значення 0,85. Також бачимо високий мультиколініарний зв'язок між індексом девальвації гривні та ВВП, тому для подальшого регресійного аналізу обрано фактори індексу інфляції та ВВП. Отже, величина коефіцієнта множинної кореляції $\mathrm{R}=0,975921$ показує якість отриманої моделі. Значення R-квадрату говорить, що на 95,2 \% на динаміку доходів домогосподарств від продажу с/г продукції вплинули обрані фактори, а 4,8 \% становлять фактори, які залишилися поза аналізом. Значення показника значущості $F$ свідчить про досто- вірність оцінювання. Отримано модель:

$$
Y=16,43+0,342528 * I I+0,057154 * B В \Pi \text {. }
$$

Результат регресійного аналізу показує, що за збільшення індексу інфляції на 100 од. доходи домогосподарств від продажу сільськогосподарської продукції знизяться на 34,3 од., а за збільшення ВВП на 100 од. - зростуть на 5,7 од.

Оцінимо ступінь впливу індексу інфляції, ВВП та індексу девальвації гривні (рис. 8) на величину доходів домогосподарств від власності (дивіденди, акції, здачі активів у найм тощо) у 2014-2018 рр. У табл. 3 побудуємо матрицю кореляційних коефіцієнтів. 


\begin{tabular}{|c|c|c|c|c|}
\hline \multicolumn{5}{|c|}{$\begin{array}{l}\text { Матриця коефіціснтів кореляційної моделі впливу зовнішніх факторів на доходи домогосподар } \\
\text { власності у 2014-2018 рр. [розроблено автором] }\end{array}$} \\
\hline & ДВ & II & ВВП & ІД \\
\hline ДВ & 1 & & & \\
\hline II & $-0,75111$ & 1 & & \\
\hline ВВП & 0,987772 & $-0,67603$ & 1 & \\
\hline ІД & $-0,92576$ & 0,617597 & $-0,88521$ & 1 \\
\hline
\end{tabular}

Провівши аналіз отриманих коефіцієнтів кореляції бачимо, що на динаміку доходів домогосподарств від власності (дивіденди, акції, здачі активів у найм тощо) найбільший ступінь впливу мав рівень ВВП, значення якого дорівнює 0,987772, що перевищує модуль 0,85 . Також варто звернути увагу на мультиколініарний зв'язок між факторами: індекс девальвації гривні та ВВП. Для подальшого регресійного аналізу обрано фактори індексу інфляції та ВВП. Так, величина коефіцієнта множинної кореляції $\mathrm{R}=0,994226$ показує якість отриманої моделі. Значення R-квадрату показує, що на 98,8 \% на динаміку доходів домогосподарств від власності (дивіденди, акції, здачі активів у найм тощо) вплинули обрані нами фактори, а 1,8 \% інші фактори. Значення показника значущості $F$ показує достовірність оцінювання. Отримано наступну модель:

$$
Y=35,35+(-0,39669) * I I+0,040265 * B B \Pi .
$$

Отже, за збільшення індексу інфляції на 100 од. доходи домогосподарств від власності (дивіденди, акції, здачі активів у найм тощо) знизяться на 39,7 од., а за збільшення ВВП на 100 од. - зростуть на 4 од.

\section{ВИСНОВКИ}

У структурі грошових доходів і сукупних ресурсів бачимо зростання майже вдвічі доходів домогосподарств від підприємницької діяльності, а також досить суттєве зростання доходів домогосподарств від продажу с/г продукції та доходів від власності. У структурі сукупних ресурсів доходи домогосподарств від підприємницької діяльності займають основну частину доходів домогосподарств від реалізації підприємницького хисту та найвищої позначки досягли у малих містах, а доходи від продажу с/г продукції та доходи від власності найбільш активно отримували домогосподарства сільських регіонів. У структурі грошових доходів: доходи домогосподарств від підприємницької діяльності становили найбільшу частку, зокрема у малих містах; доходи від продажу с/г продукції найвищими зафіксовано у селах проте з тенденцією до зниження; доходи від власності найбільшого рівня досягли у селах.

Провівши аналіз доходів домогосподарств від реалізації підприємницького хисту у структурі грошових доходів і сукупних ресурсів за геолокацією бачимо, що найвищого рівня вони досягли 3 наступною особливістю: доходи домогосподарств від підприємницької діяльності - у великих і малих містах, доходи домогосподарств від продажу с/г продукції та доходи домогосподарств від власності - у селах.

Аналізуючи доходи домогосподарств від підприємницької діяльності за регіонами бачимо, що най- вищого рівня вони досягли з такою особливістю: у структурі грошових доходів і сукупних ресурсів - у Закарпатській, Тернопільській, Чернігівській, Вінницькій, Донецькій, Запорізькій областях та м. Києві; у структурі грошових доходів - у Закарпатській, Тернопільській, Чернігівській, Донецькій, Запорізькій областях; у структурі сукупних ресурсів - у Закарпатській, Чернігівській, Тернопільській та Запорізькій областях. Доходи домогосподарств від продажу сільськогосподарської продукції найвищого рівня за регіонами досягли 3 наступною особливістю: у структурі грошових доходів і сукупних ресурсів та у структурі грошових доходів - у Волинській та Тернопільській областях, у структурі сукупних ресурсів- у Луганській та Тернопільській областях. Доходи домогосподарств від власності за регіонами найвищого рівня досягли у структурі грошових доходів і сукупних ресурсів та у структурі сукупних ресурсів - у Кіровоградській і Тернопільській, областях, у структурі грошових доходів - у Хмельницькій та Тернопільській областях.

За результатами кореляційно-регресійного аналізу впливу факторів зовнішнього середовища на доходи домогосподарств від підприємницької діяльності, доходи від продажу с/г продукції і доходи від власності встановлено, що найбільший вплив на розмір цих доходів чинили такі фактори як коливання індексу інфляції та рівень ВВП.

Ймовірно спадна тенденція деяких категорій доходів від реалізації підприємницького хисту, зокрема у частині доходів від продажу с/г продукції, саме у сільських домогосподарств, які $€$ найбільш чутливими до економічних коливань, пов'язана із негативним впливом таких факторів зовнішнього середовища як політичне становище, податкова політика, рівень інфляції, коливання курсів валют і рівня ВВП, ціновим та конкурентним середовищем на ринках, а також іншими факторами внутрішнього середовища домогосподарств. Тому рекомендується проведення комплексного перегляду та покращення умов здійснення підприємницької діяльності дрібних підприємців на загальнодержавному рівні.

Наукова цінність проведеного дослідження полягає у спрямуванні результатів роботи на визначення основних трендів розвитку доходів домогосподарств від підприємницької діяльності, що у підсумку дозволить отримувати якісну інформацію про рівень розвитку приватного бізнесу як підприємцям, так і державним установам, використовувати дані дослідження для прогнозування його майбутнього розвитку, а також використовувати результати дослідження у розробці нормативних актів з регулювання діяльності 
підприємництва на загальнодержавному рівні.

3 метою подальших наукових досліджень доцільно також провести економічний, статистичний та факторний аналіз структури та динаміки показників діяльності вітчизняних приватних підприємств, що дозволить оцінити рівень дохідності домогосподарств, які є їх власниками і здійснюють пряме або опосередковане управління юридичними організаціями.

\section{Список використаних джерел}

1. Дворник І.В. Формування доходів сільського населення: автореф. дис. ... канд. екон. наук: 08.00.07. Київ. 2018. 21 с. URL: https://idss.org.ua/avtoref/2018 Dvornik ref.pdf

2. Заїка А.М. Стан формування доходів домогосподарсте y сучасних умовах. Науковий вісник Ужгородського університету. 2017. Bun. 1. C. 253-257.

3. Кізима Т.О. Фінанси домогосподарств: конщептуальні засади теорії і практики: дис. ... д-ра екон. наук: 08.00.08. Тернопіль, 2011. 514 c.

4. Лілич Л., Мостенеиь С. Управління доходами та видатками домогосподарств в умовах ринку. Економіст. 2013. № 7. C. 47-53.

5. Потьомкін С.К., Козлова І.М. Аналіз структури доходів $i$ витрат домогосподарств. Глобальні та національні проблеми економіки. 2016. Вип. 13. С. 172-179.

6. Семенченко А.В. Регулювання доходів населення у контексті сочіальної стратифікації суспільства: дис. ... канд екон. наук: 08.00.07. Харків, 2017. 317 с.

7. Брич В.Я. Трансформація ринку прачі та проблеми підвищення життєвого рівня населення: методологія, практика, шляхи вирішення: монографія. Тернопіль: Економічна думка, 2003. 375 c.

8. Перит І.О. Економічна сутність домогосподарств як учасників підприємницької діяльності. Економічний дискурс. 2019. Bun. 3. С. 66-74

9. Витрати і ресурси домогосподарств України у 2014 2016 роках. Державна Служба Статистики Украйни. URL: http://www.ukrstat.gov.ua/druk/publicat/Arhiv_u/17/Arch_vrd_z b.htm

10. Витрати і ресурси домогосподарств Украӥни у 2017 рочі. Державна Служба Статистики Украӥни. URL: http://www.ukrstat.gov.ua/druk/publicat/kat_u/2018/zb/07/zb_vr du2017 pdf.pdf

11. Витрати і ресурси домогосподарств Украӥни у 2018 рочі. Державна Служба Статистики України. URL: http://www.ukrstat.gov.ua/druk/publicat/kat_u/2019/zb/06/zb_vr du2018.pdf

12. Перит І.О. Аналіз динаміки та факторів впливу на доходи домогосподарств від підприємницької діяльності в умовах сучасної економіки. Сталий розвиток економіки. 2016. № 1(30). C. 214-221.

\section{References}

1. Dvornyk I.V. Formation of income of the rural population: abstract ... cand. econ. sciences: 08.00.07. Kyiv. 2018. 21 p. URL: https://idss.org.ualavtoref/2018 Dvornik ref.pdf (in Ukrainian)

2. Zaika A.M. The state of household income formation in modern conditions. Scientific Bulletin of Uzhhorod University. 2017. Issue 1. pp. 253-257. (in Ukrainian)

3. Kizyma T.O. Household finance: conceptual foundations of theory and practice: diss. ... Dr. econ. sciences: 08.00.08. Ternopil, 2011. 514 p. (in Ukrainian)

4. Lilych L., Mostenets S. Management of income and expenditure of households in market conditions. Economist. 2013. №7. pp. 47-53. (in Ukrainian)

5. Potomkin S.K., Kozlova I.M. Analysis of the structure of income and expenditure of households. Global and national economic problems. 2016. Issue 13. pp. 172-179. (in Ukrainian)

6. Semenchenko A.V. Regulation of income in the context of social stratification of society: diss. ... cand. econ. sciences: 08.00.07. Kharkiv, 2017. 317 p. (in Ukrainian)

7. Brych V.Ya. Transformation of the labor market and problems of raising the living standards of the population: methodology, practice, solutions: monograph. Ternopil: Economic Thought, 2003. 375 p. (in Ukrainian)

8. Peryt I.O. Economic essence of households as participants in entrepreneurial activity. Economic discourse. 2019. Issue 3. pp. 66-74 (in Ukrainian)

9. Expenditures and resources of Ukrainian households in 2014-2016. State Statistics Service of Ukraine. URL: http://www.ukrstat.gov.ua/druk/publicat/Arhiv_u/17/Arch_vrd_z b.htm (in Ukrainian)

10. Expenditures and resources of Ukrainian households in 2017. State Statistics Service of Ukraine. URL: http://www.ukrstat.gov.ua/druk/publicat/kat_u/2018/zb/07/zb_vr du2017 pdf.pdf (in Ukrainian)

11. Expenditures and resources of Ukrainian households in 2018. State Statistics Service of Ukraine. URL: http://www.ukrstat.gov.ua/druk/publicat/kat_u/2019/zb/06/zb_vr du2018.pdf (in Ukrainian)

12. Peryt I.O. Analysis of the dynamics and factors influencing household incomes from entrepreneurial activity in the modern economy. Sustainable economic development. 2016. № 1 (30). pp. 214-221. (in Ukrainian) 